\title{
Effects of intravenous glucose infusion and nutritional balance on serum concentrations of nonesterified fatty acids, glucose, insulin, and progesterone in nonlactating dairy cows
}

\author{
F. V. R. Vieira, ${ }^{*}$ C. N. Lopes, ${ }^{*}$ B. I. Cappellozza, ${ }^{*}$ A. B. Scarpa, ${ }^{*}$ R. F. Cooke, $†$ and J. L. M. Vasconcelos ${ }^{* 1}$ \\ *Department of Animal Production, São Paulo State University, Botucatu 18168-000, Brazil \\ †Eastern Oregon Agricultural Research Center, Oregon State University, Burns 97720
}

\section{ABSTRACT}

The objective of this study was to evaluate serum concentrations of nonesterified fatty acids, glucose, insulin, and progesterone in nonlactating dairy cows according to nutritional balance and glucose infusion. Ten nonlactating, ovariectomized Gir $\times$ Holstein cows were stratified by body weight (BW) and body condition score (BCS) on d -28 of the study, and randomly assigned to 1 ) negative nutrient balance (NB) or 2 ) positive nutrient balance (PB). From $\mathrm{d}-28$ to $\mathrm{d} 0$, cows were allocated according to nutritional treatment (5 cows/treatment) into 2 low-quality pastures with reduced forage availability. However, PB cows individually received, on average, $3 \mathrm{~kg} / \mathrm{cow}$ per day (as-fed) of a concentrate during the study. All cows had an intravaginal progesterone releasing device inserted on $\mathrm{d}-14$, which remained in cows until the end of the study. Cow $\mathrm{BW}$ and BCS were assessed again on $\mathrm{d} 0$. On $\mathrm{d} 0$, cows within nutritional treatment were randomly assigned to receive, in a crossover design containing 2 periods of $24 \mathrm{~h}$ each, 1) intravenous glucose infusion (GLU; $0.5 \mathrm{~g}$ of glucose $/ \mathrm{kg}$ of BW, as a $5 \%$ glucose solution administered, on average, at $32 \mathrm{~mL} / \mathrm{min}$ over a 3 -h period), or 2) intravenous saline infusion (SAL; $0.9 \%$ solution infused on average at $32 \mathrm{~mL} / \mathrm{min}$ over a 3 -h period). Prior to the beginning of each period, all cows were fasted for $12 \mathrm{~h}$. Blood samples were collected, relative to the beginning of the infusion, at -12 and $-11.5 \mathrm{~h}$ (beginning of fasting), and at $-0.5,0,0.5,1,2,3,4,5$, and $6 \mathrm{~h}$. Following the last blood collection of period 1, cows received $(\mathrm{PB})$ or not $(\mathrm{NB})$ concentrate and were returned to their respective pastures. Changes in BCS and $\mathrm{BW}$ were greater in $\mathrm{NB}$ cows compared with $\mathrm{PB}$ cows $(-0.60$ and $-0.25 \pm 0.090$ for BCS, respectively; -22.4 and $1.2 \pm 6.58 \mathrm{~kg}$ for BW, respectively). Cows receiving GLUC had greater glucose concentrations from 0.5 to $3 \mathrm{~h}$ relative to infusion compared with SAL

Received January 6, 2010

Accepted March 22, 2010

${ }^{1}$ Corresponding author: vasconcelos@fca.unesp.br cows. Insulin concentrations were greater in $\mathrm{PB}$ cows assigned to GLUC compared with SAL cohorts at 0.5 and $3 \mathrm{~h}$ following infusion, whereas NB cows assigned to GLUC had greater insulin concentrations compared with SAL cohorts at $0.5,1,2$, and $3 \mathrm{~h}$. Progesterone concentrations were greater in $\mathrm{PB}$ cows assigned to GLUC at 2, 3, and $4 \mathrm{~h}$ following infusion compared with SAL cohorts. In conclusion, the effects of glucose infusion on serum concentrations of insulin and progesterone in nonlactating dairy cows were dependent on cow nutritional status.

Key words: glucose infusion, insulin, nutritional status, progesterone

\section{INTRODUCTION}

During the last few decades in the United States, milk production per dairy cow increased whereas reproductive efficiency decreased (Lucy, 2001). This relationship can be associated with several factors, such as increased incidence of metabolic and reproductive diseases, intensified postpartum negative energy balance, and consequent increased postpartum body fat mobilization (Opsomer et al., 2000; Lucy, 2001). As an example, negative energy balance leads to reduced postpartum circulating concentrations of hormones such as progesterone (P4) and insulin (Sangsritavong et al., 2002; Butler, 2005).

Progesterone is a hormone required for adequate attainment of puberty, resumption of estrous cycles, and also establishment and maintenance of pregnancy (Gonzalez-Padilla et al., 1975; Spencer and Bazer, 2002; Looper et al., 2003). Several researchers have reported that blood concentrations of $\mathrm{P} 4$ in cattle before or after breeding have been positively associated with conception rates (Fonseca et al., 1983; Folman et al., 1990; Demetrio et al., 2007). Insulin is considered a metabolic mediator between nutrition and reproduction of cattle, and modulates reproductive function by positively influencing LH synthesis and release by the pituitary (Monget and Martin, 1997), follicular devel- 
opment (Diskin et al., 2003; Webb et al., 2004), and ovarian steroid synthesis (Spicer and Echternkamp, 1995; Gutiérrez et al., 1997; Wettemann and Bossis, 2000). Accordingly, Gong et al. (2002) reported that dairy cows with elevated circulating insulin concentrations postcalving had shorter postpartum interval to ovulation compared with cohorts with reduced insulin concentrations.

In addition, insulin may affect reproduction in cattle by modulating hepatic expression of enzymes associated with catabolism of $\mathrm{P} 4$, such as cytochrome $\mathrm{P} 450$ 2C and P450 3A (Murray, 1991; Lemley et al., 2008). Previous efforts from our research group established that dairy and beef cows with elevated insulin concentrations had greater mean $\mathrm{P} 4$ concentrations compared with cows with reduced insulin concentrations (Moriel et al., 2008; Lopes et al., 2009). However, these studies evaluated cows in moderate to positive energy balance. Insulin metabolism is highly dependent on nutritional status, and its synthesis, release, and metabolic effects differ in cattle in negative nutritional balance, such as periparturient dairy cows, compared with cattle in positive nutritional balance (Hove, 1978; Veerkamp et al., 2003).

To further test these mechanisms, we hypothesized that i.v. glucose infusion increases circulating concentrations of insulin and reduces hepatic clearance of $\mathrm{P} 4$ in dairy cows, but that these effects are dependent on cow nutritional status. Our objectives were to evaluate serum concentrations of NEFA, glucose, insulin, and $\mathrm{P} 4$ in nonlactating dairy cows in negative or positive nutritional balance, and administered or not with i.v. glucose infusion.

\section{MATERIALS AND METHODS}

This experiment was conducted at the São Paulo State University, Lageado Experimental Station, located in Botucatu, São Paulo, Brazil. The animals utilized were cared for in accordance with the practices outlined in the Guide for the Care and Use of Agricultural Animals in Agricultural Research and Teaching (FASS, 1999).

\section{Animals and Diets}

Ten nonlactating, nonpregnant, and ovariectomized Gir $\times$ Holstein cows $(\mathrm{BW}=587 \pm 22.8 \mathrm{~kg} ; \mathrm{BCS}=2.5$ \pm 0.07 ) were stratified by BW and BCS (Wildman et al., 1982) and randomly assigned to 1 of 2 nutritional treatments ( 5 cows/group) on $\mathrm{d}-28$ of the experiment: 1) negative nutrient balance (NB) or 2) positive nutrient balance $(\mathbf{P B})$. From $\mathrm{d}-28$ to $\mathrm{d} 0$, cows were allocated according to nutritional treatment into 2 Brachiaria brizantha pastures with low forage quality (average of $53 \%$ total digestible nutrients, $7.1 \% \mathrm{CP}$, and $76.4 \%$ NDF; DM basis) and availability (average of $4.5 \mathrm{~kg}$ of $\mathrm{DM} / \mathrm{cow}$ daily). Both groups received a complete commercial mineral and vitamin mix $(7.7 \%$ $\mathrm{Ca}, 4.0 \% \mathrm{P}, 3.0 \% \mathrm{Na}, 0.20 \% \mathrm{~K}, 0.20 \% \mathrm{Mg}, 2.0 \% \mathrm{~S}$, $0.002 \% \mathrm{Co}, 0.03 \% \mathrm{Cu}, 0.002 \% \mathrm{I}, 0.02 \% \mathrm{Mn}, 0.13 \% \mathrm{Zn}$, and $0.02 \% \mathrm{~F}$ ) and water for ad libitum consumption throughout the experiment. However, $\mathrm{PB}$ cows received daily (as-fed basis), at $1200 \mathrm{~h}, 2 \mathrm{~kg} /$ cow of a supplemental concentrate from d -28 to $\mathrm{d}-14$, and $4 \mathrm{~kg} /$ cow of the same concentrate from $d-13$ to $d 0$. Supplements were offered individually to cows through self-locking head gates.

The supplemental concentrate consisted of (DM basis) $62.5 \%$ of ground corn, $29 \%$ of soybean meal, $5 \%$ of mineral mix $(18 \% \mathrm{Ca}, 10.7 \% \mathrm{Na}, 8 \% \mathrm{P}, 1.2 \% \mathrm{~S}$, $0.5 \% \mathrm{Mg}, 0.13 \% \mathrm{Cu}, 0.007 \% \mathrm{Co}$, and $0.007 \% \mathrm{I}), 2.5 \%$ of limestone, and $1 \%$ of urea. Nutritional content of concentrate was estimated to be (DM basis) $76 \%$ of total digestible nutrients, $22.4 \%$ of $\mathrm{CP}$, and $12.5 \%$ of NDF. From d -28 to d 0, forage mass was evaluated weekly according to the techniques described by Vendramini et al. (2008), whereas forage and concentrate samples were also collected weekly and analyzed for nutritional content by a bromatology laboratory (São Paulo State University, Botucatu, Brazil). Nutritional treatments were designed according to the Cornell Net Carbohydrate and Protein System model (Fox et al., $2004)$ and formulated to induce BW loss $(-0.9 \mathrm{~kg} / \mathrm{d})$ in NB cows and BW gain $(0.2 \mathrm{~kg} / \mathrm{d})$ in $\mathrm{PB}$ cows.

\section{Glucose Infusion and Sampling}

On d 0, cows within nutritional treatment were randomly assigned to receive, in a crossover design containing 2 periods of $24 \mathrm{~h}$ each (d 1 and d 2), 1) i.v. glucose infusion $(0.5 \mathrm{~g} / \mathrm{kg}$ of BW; GLUC), or 2) i.v. saline infusion (SAL). Prior to the beginning of each period, all cows were fasted for $12 \mathrm{~h}$, beginning at 1530 $\mathrm{h}$ of the day before each period (d 0 and 1 , respectively; approximately $5 \mathrm{~h}$ after PB cows completely consumed their supplements). Blood samples were collected, relative to the beginning of the infusion, at -12 and -11.5 $\mathrm{h}$ (beginning of fasting), and at $-0.5,0,0.5,1,2,3,4$, 5 , and $6 \mathrm{~h}$. Following the last blood collection of period 1 , cows received $(\mathrm{PB})$ or not $(\mathrm{NB})$ the supplementation and returned to their respective pastures. Cows were fasted before infusion to prevent any confounding effects between feed intake and infusion treatments on circulating concentrations of P4 (Vasconcelos et al., 2003).

Immediately before infusions, all cows were fitted with indwelling jugular catheters according to the procedures described by Curley et al. (2008). Treatments 
(GLUC or SAL) were administered via catheters over a period of $3 \mathrm{~h}$ (on average $32 \mathrm{~mL} / \mathrm{min}$ ); GLUC cows received a 5\% (wt/vol) glucose solution (90:10 solution of physiological saline and Glicose 50\%; Laboratório Prado S.A.; Curitiba, Brazil) according to their BW, whereas SAL cows received a comparable volume of physiological saline $(0.9 \%)$. Catheters were removed after infusion was complete.

Cow BW and BCS were assessed at the beginning of the experiment $(\mathrm{d}-28)$ and before fasting on $\mathrm{d} 0$ to determine nutritional treatment effects on $\mathrm{BW}$ and BCS change during the experiment.

\section{Progesterone Implants and Blood Analysis}

From $\mathrm{d}-28$ to $\mathrm{d}-15$, all cows were inserted with a previously used (third use) intravaginal progesterone releasing device (CIDR, originally containing $1.9 \mathrm{~g}$ of P4; Pfizer Animal Health, Sao Paulo, Brazil) to initially expose and adapt cows to exogenous $\mathrm{P} 4$. Cows received a new CIDR on $\mathrm{d}-14$, which remained in the cows until the end of the experiment.

Blood samples were collected via jugular venipuncture into commercial blood collection tubes (Vacutainer, 10 mL, Becton Dickinson, Franklin Lakes, NJ), placed immediately on ice, and centrifuged at $3,000 \times g$ for 30 min for serum collection. Harvested serum was stored frozen at $-20^{\circ} \mathrm{C}$ until further processing. Quantitative colorimetric kits were used to determine concentrations of glucose (Katal Biotecnológica Ind. Com. Ltda., Belo Horizonte, Brazil) and NEFA (Randox Brasil Ltda., São Paulo, Brazil). Concentrations of P4 and insulin were determined using a Coat-A-Count kit (DPC Diagnostic Products Inc., Los Angeles, CA) solid-phase ${ }^{125} \mathrm{I}$ RIA that was previously validated for bovine samples (Moriel et al., 2008). All samples were analyzed within one assay for each hormone. The intraassay CV was $5.8 \%$ for $\mathrm{P} 4$ and $6.9 \%$ for insulin. The minimum detectable concentrations were $0.1 \mathrm{ng} / \mathrm{mL}$ of $\mathrm{P} 4$ and 0.05 $\mu \mathrm{IU} / \mathrm{mL}$ of insulin.

\section{Statistical Analysis}

Data were analyzed using the MIXED procedure of SAS (SAS Inst. Inc., Cary, NC) and Satterthwaite approximation to determine the denominator degrees of freedom for the tests of fixed effects. The model statement used for BW and BCS change contained the effects of nutritional treatment (NB and PB). Data from blood samples collected at the beginning of fasting were analyzed independently of those collected immediately before or following infusions because of the significant interval and fasting effect between these collections, because measures on the same animal taken close in time are potentially more highly correlated than those taken far apart in time (Littell et al., 1998). The model statement used for hormones and metabolites at the beginning of fasting contained the effects of nutritional treatment, collection hour, the nutritional treatment $x$ collection hour interaction, and period as an independent variable. Data were analyzed using cow(nutritional treatment) as random variable. The specified term for the repeated statement was collection hour, subject was cow(nutritional treatment $\times$ period), and the covariance structure used was autoregressive, which provided the best fit for these analyses according to the Akaike information criterion. The model statement used for hormones and metabolites immediately prior, during, and after infusion ( -0.5 to $6 \mathrm{~h}$ relative to infusion) contained the effects of nutritional treatment (NB and $\mathrm{PB}$ ), infusion treatment (GLUC and SAL), collection hour, period as an independent variable, and all 2-way and 3-way interactions among nutritional treatment, infusion treatment, and collection hour. Data were analyzed using cow(nutritional treatment) as random variable. The specified term for the repeated statement was collection hour, subject was cow(nutritional treatment $\times$ infusion treatment $\times$ period), and the covariance structure used was autoregressive, which provided the best fit for these analyses according to the Akaike information criterion. All results are reported as least squares means, and means were separated using LSD. Significance was set at $P \leq 0.05$, and tendencies were declared if $P>0.05$ and $\leq 0.10$. Results are reported according to treatment effects if no interactions were significant or according to the highest order interaction detected.

\section{RESULTS AND DISCUSSION}

During the experiment, BCS loss was greater $(P=$ 0.02; Table 1) in NB cows compared with $\mathrm{PB}$ cows $(-0.60$ vs. -0.25 , respectively; $\mathrm{SEM}=0.090)$. Similarly, NB cows lost BW (Table 1) during the experiment, whereas BW of PB cows was almost unchanged $(-22.4$ vs. $1.2 \mathrm{~kg}$ of $\mathrm{BW}$ change, respectively; $P=0.04$, SEM $=6.58)$. These outcomes are in accordance with the differences in nutrient intake and consequent nutritional status between NB and PB cows.

However, concentrations of NEFA were similar $(P=$ 0.65 ; Table 1) between $\mathrm{PB}$ and $\mathrm{NB}$ cows at the beginning of fasting ( 0.22 vs. $0.21 \mathrm{mmol} / \mathrm{L}$, respectively; SEM = 0.021), despite differences in nutrient intake, $\mathrm{BCS}$, and BW change. Also, no infusion effects were detected on serum NEFA, given that GLUC cows had similar $(P=0.17)$ NEFA concentrations compared with SAL cows $(0.21$ vs. $0.23 \mathrm{mmol} / \mathrm{L}$, respectively; SEM $=0.014)$, independently of nutritional treatment 
Table 1. Changes in BW and BCS, and serum concentrations of NEFA, glucose, insulin, and progesterone of nonlactating dairy cows in negative $(\mathrm{NB})$ or positive $(\mathrm{PB})$ nutrient balance from $\mathrm{d}-28$ to $\mathrm{d} 1$ of the experiment $^{1}$

\begin{tabular}{|c|c|c|c|c|}
\hline \multirow[b]{2}{*}{ Item } & \multicolumn{2}{|c|}{ Treatment $^{2}$} & \multirow[b]{2}{*}{ SEM } & \multirow[b]{2}{*}{$P$-value } \\
\hline & NB & $\mathrm{PB}$ & & \\
\hline BCS change $(1 \text { to } 5 \text { scale })^{3}$ & -0.60 & -0.25 & 0.090 & 0.02 \\
\hline BW change, kg & -22.4 & 1.2 & 6.58 & 0.04 \\
\hline $\mathrm{NEFA}, \mathrm{mmol} / \mathrm{L}$ & 0.21 & 0.22 & 0.021 & 0.65 \\
\hline Glucose, $\mathrm{mg} / \mathrm{dL}$ & 72.0 & 67.3 & 1.60 & 0.05 \\
\hline Insulin, $\mu \mathrm{IU} / \mathrm{mL}$ & 17.86 & 27.1 & 2.865 & 0.04 \\
\hline Progesterone, ng/mL & 1.17 & 0.93 & 0.082 & 0.05 \\
\hline
\end{tabular}

${ }^{1}$ Changes in BCS and BW were calculated from measures obtained on $\mathrm{d}-28$ and $\mathrm{d} 0$. Serum samples were collected at the beginning of the fasting period on $\mathrm{d} 1$.

${ }^{2} \mathrm{NB}$ cows were maintained in a Brachiaria brizantha pasture with low forage quality and availability; PB cows were maintained in a $B$. brizantha pasture with low forage quality and availability, but received daily $2 \mathrm{~kg} /$ cow of a supplemental concentrate from $\mathrm{d}-28$ to $\mathrm{d}-14$, and $4 \mathrm{~kg} /$ cow of the same concentrate from $\mathrm{d}-13$ to d 1 .

${ }^{3}$ According to Wildman et al. (1982).

$(P=0.80)$ or the interaction (nutritional treatment $\times$ infusion treatment; $P=0.13$ ). These results were unexpected because circulating NEFA typically becomes elevated with inadequate nutrient intake and body fat mobilization in cattle (Grummer, 1995). In addition, previous research efforts demonstrated that circulating NEFA decreases in nonlactating or lactating dairy cows receiving glucose precursors, such as propylene glycol, particularly when cows are under a negative energy balance (Christensen et al., 1997; Butler et al., 2006).

At the beginning of fasting, glucose concentrations were greater $(P=0.05$; Table 1$)$ in NB cows compared with PB cows (72.0 vs. $67.3 \mathrm{mg} / \mathrm{dL}$, respectively; SEM $=1.60)$, despite the differences in nutrient intake between nutritional treatments. Circulating glucose concentrations in cattle are highly dependent on hepatic gluconeogenesis from dietary ingredients following digestion (Young, 1977), particularly propionate originating from rumen fermentation (Reynolds et al., 1994; Huntington, 1997; Reynolds, 2005). However, cattle in inadequate nutritional status may use other gluconeogenic substrates, such as endogenous amino acids and glycerol from triacylglycerol, and also enhance gluconeogenesis to compensate for nutritional deficiencies and prevent significant decreases in circulating glucose, given that glucose is essential for many maintenance and productive functions of ruminants (Huntington, 1997). Supporting this rationale and our results, Velez and Donkin (2005) reported that feed-restricted lactating dairy cows had greater plasma glucose concentrations and increased hepatic expression of a gluconeogenic enzyme (pyruvate carboxylase) compared with cohorts with ad libitum feed intake.

In agreement with the experimental design, an infusion treatment $\times$ time interaction was detected $(P<$
0.01) for serum glucose independently of nutritional treatment $(P=0.77)$ or the resultant interaction $(P$ $=0.18$ ) because GLUC cows had greater glucose concentrations from 0.5 to $3 \mathrm{~h}$ relative to the beginning of infusion time compared with SAL cows (Figure 1).

At the beginning of fasting, serum insulin concentrations were greater $(P=0.04$; Table 1$)$ in $\mathrm{PB}$ cows compared with NB cows $(27.12$ vs. $17.86 \mu \mathrm{IU} / \mathrm{mL}$, respectively; $\mathrm{SEM}=2.865)$. These outcomes agree with differences in nutrient intake between $\mathrm{PB}$ and NB cows, given that circulating insulin concentrations have been positively associated with feed intake in cattle (Vizcarra et al., 1998; Bossis et al., 2000; Lapierre et al., 2000). Conversely, insulin is synthesized and secreted mainly in response to blood glucose concentrations (Nussey and Whitehead, 2001), which were greater in NB cows compared with PB cows. However, insulin is also secreted in response to other stimuli, such as gastrointestinal hormones and neural/paracrine mechanisms associated with feed intake (Nussey and Whitehead, 2001).

A nutritional treatment $x$ infusion treatment $\times$ time interaction was detected $(P<0.01)$ for serum insulin concentrations because insulin responses to glucose infusion were reliant on nutritional status (Figure 2). Following infusion, PB cows assigned to GLUC had greater insulin concentrations compared with SAL cohorts at 0.5 and $3 \mathrm{~h}$, indicating a biphasic increase in circulating insulin. On the other hand, NB cows assigned to GLUC had consistently greater insulin concentrations compared with SAL cohorts at $0.5,1,2$, and $3 \mathrm{~h}$ following infusion, whereas a biphasic response was not detected. Hove (1978) also reported biphasic and single-phase insulin increases following glucose infusion in lactating dairy cows with adequate or inadequate feed intake, respectively, and suggested that 


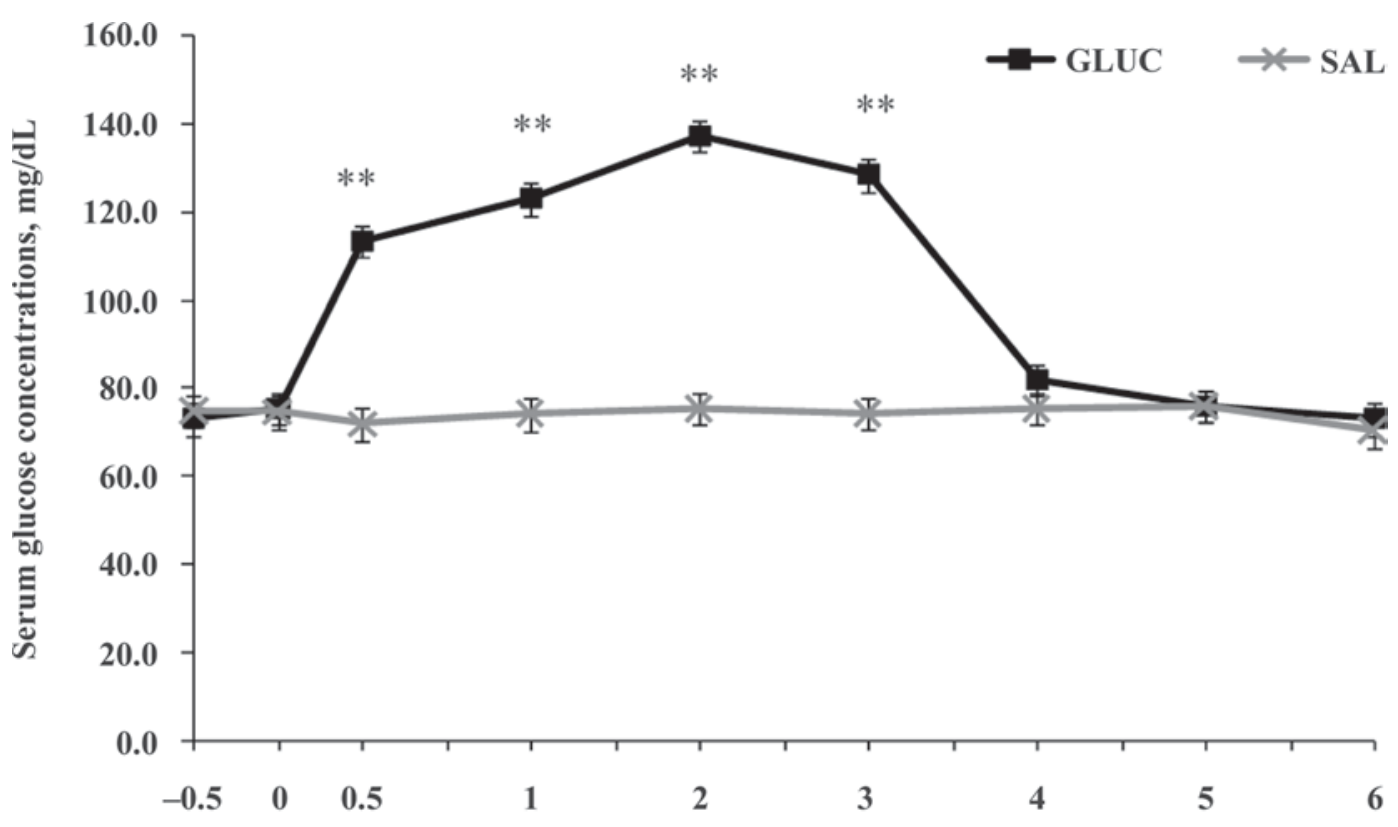

Hours relative to treatment infusion

Figure 1. Serum concentrations of glucose $(\mathrm{mg} / \mathrm{dL})$ in nonlactating cows infused intravenously with a $5 \%$ glucose solution (GLUC; $0.5 \mathrm{~g}$ of glucose $/ \mathrm{kg}$ of BW, infused on average at $32 \mathrm{~mL} / \mathrm{min}$ over a 3 -h period) or with physiological saline (SAL; $0.9 \%$ solution infused on average at $32 \mathrm{~mL} / \mathrm{min}$ over a 3 -h period). Treatments were infused immediately following blood sampling at $0 \mathrm{~h}$. An infusion treatment $\times$ time interaction was detected $(P<0.01)$. Treatment comparison within time: $* * P<0.01$.

these differences can be attributed to altered reserves of proinsulin in pancreatic $\beta$-cells due to nutritional status (Nelson and Cox, 2005). However, the results presented herein and by Hove (1978) are not sufficient to elucidate this mechanism in cattle; therefore, further research is required to address this subject.

At the beginning of fasting, serum $\mathrm{P} 4$ concentrations were greater $(P=0.05$; Table 1$)$ in NB cows compared with $\mathrm{PB}$ cows (1.17 vs. $0.93 \mathrm{ng} / \mathrm{mL}$, respectively; SEM $=0.082$ ). The cows used in the present study were ovariectomized; therefore, the main source for circulating $\mathrm{P} 4$ was the CIDR. These differences in $\mathrm{P} 4$ concentrations between $\mathrm{NB}$ and $\mathrm{PB}$ cows at the beginning of fasting can be attributed to many factors. First, PB cows had increased feed intake compared with NB cows; greater feed intake leads to increased hepatic blood flow and consequent hepatic P4 catabolism (Sangsritavong et al., 2002). Second, the adrenal gland is also capable of synthesizing significant amounts of P4 as an intermediate of corticoid synthesis when stimulated by stressors (O'Connor et al., 2000), and feed restriction can increase adrenal synthesis of cortisol (Murayama et al., 1986; Ward et al., 1992; Henricks et al., 1994) and perhaps adrenal $\mathrm{P} 4$ production (Cooke and Arthington, 2009). Third, P4 is stored into adipose tissues and can be released into the circulation when body fat is mobilized (Hamudikuwanda et al., 1996). Therefore, one can also speculate that $\mathrm{P} 4$ originating from the CIDR or adrenal glands was stored in fat tissues of NB cows, and because of significant BW and BCS loss (Table 1), it was released into the bloodstream and contributed to the increased serum $\mathrm{P} 4$ concentrations detected in NB cows compared with PB cows. Nevertheless, NEFA concentrations were similar between $\mathrm{NB}$ and $\mathrm{PB}$ cows at the beginning of fasting, and NEFA typically mirror the extent of body fat mobilization and correlate with P4 release from adipose tissues in cattle (Grummer, 1995; Hamudikuwanda et al., 1996).

A nutritional treatment $x$ infusion treatment $x$ time interaction was detected $(P<0.01$; Figure 3$)$ for serum $\mathrm{P} 4$ concentrations mainly because an infusion effect $\times$ time interaction was detected for PB cows $(P$ $<0.01)$ but not for NB cows $(P=0.54)$. Further, PB cows assigned to receive GLUC had greater $(P<0.01)$ mean $\mathrm{P} 4$ concentrations from $-0.5 \mathrm{~h}$ to $6 \mathrm{~h}$ relative to infusion compared with $\mathrm{PB}$ cows assigned to receive SAL (1.19 vs. $0.83 \mathrm{ng} / \mathrm{mL}$, respectively; $\mathrm{SEM}=0.119$ ). These results, supporting our hypothesis, indicate that serum P4 concentrations were only altered by i.v. glucose infusion and subsequent increase in insulin concentrations within cows with adequate nutritional status. This increase can be attributed mainly to reduced hepatic catabolism of $\mathrm{P} 4$ in $\mathrm{PB}$ cows receiving GLUC compared with SAL cohorts, given that all cows were 


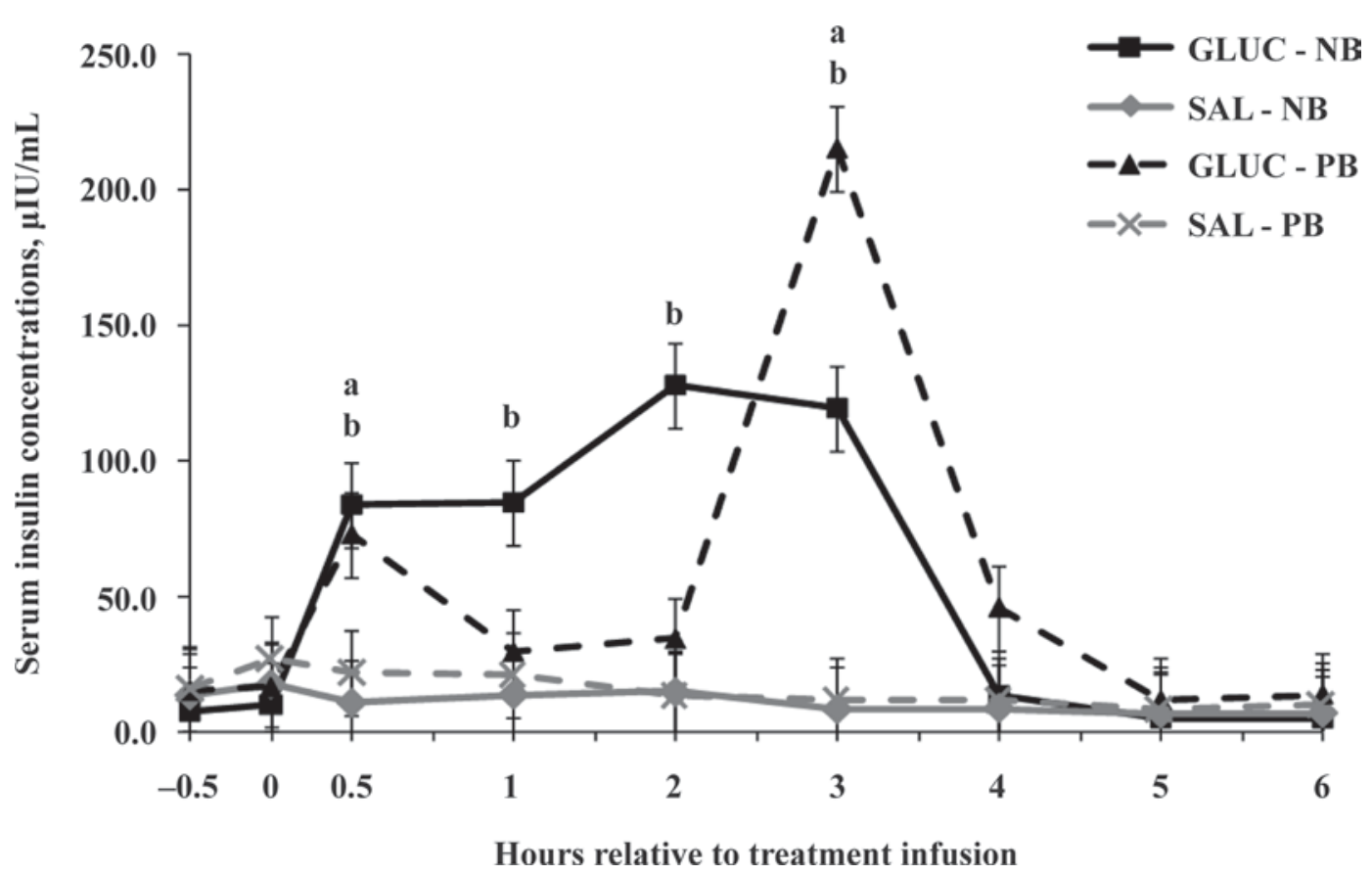

Figure 2. Serum concentrations of insulin $(\mu \mathrm{IU} / \mathrm{mL})$ in nonlactating cows in negative (NB) or positive (PB) nutrient balance, and infused intravenously with a $5 \%$ glucose solution (GLUC; $0.5 \mathrm{~g}$ of glucose $/ \mathrm{kg}$ of BW, infused on average at $32 \mathrm{~mL} / \mathrm{min}$ over a 3 -h period) or physiological saline (SAL; $0.9 \%$ solution infused on average at $32 \mathrm{~mL} / \mathrm{min}$ over a 3 -h period). Treatments were infused immediately following blood sampling at 0 h. A nutritional treatment $\times$ infusion treatment $\times$ time interaction was detected $(P<0.01)$. Hours with letter designation indicates the following treatment differences $(P<0.05)$ : $\mathrm{a}=$ GLUC-PB vs. SAL-PB; $\mathrm{b}=$ GLUC-NB vs. SAL-NB.

fasted to eliminate effects of feed intake on circulating P4 concentrations (Vasconcelos et al., 2003) and were ovariectomized and inserted with a CIDR at the same time and thus had equivalent sources of exogenous P4. Supporting the current findings, previous efforts from our research group indicated that ovariectomized cows in moderate to positive energy balance, inserted with CIDR, and with elevated insulin concentrations had greater mean P4 concentrations compared with cohorts with reduced insulin concentrations (Moriel et al., 2008; Lopes et al., 2009).

Other authors reported that lactating dairy cows drenched daily with propylene glycol $(500 \mathrm{~mL} / \mathrm{cow}$ daily), from $\mathrm{d}-10$ to $\mathrm{d} 25$ relative to parturition, had increased plasma concentrations of insulin during the study and reduced expression of hepatic P450 3A on d 25 compared with cohorts drenched with water (Butler et al., 2006; Lemley et al., 2008). Moreover, lactating dairy cows receiving continuous i.v. insulin infusion (1 $\mu \mathrm{g} / \mathrm{kg}$ of $\mathrm{BW}$ per $\mathrm{h}$ ) from $\mathrm{d} 10$ to $\mathrm{d} 14$ postpartum had increased plasma concentrations of insulin during the infusion period and reduced expression of hepatic P450 2A and P450 3A on d 14 compared with cohorts infused with saline (Butler et al., 2003; Lemley et al., 2008). Compared with the results reported herein, these cited studies (Butler et al., 2003, 2006; Lemley et al., 2008) reported inhibitory effects of insulin on hepatic expression of $\mathrm{P} 4$ catabolic enzymes in dairy cows under negative nutritional balance. However, these authors did not evaluate plasma P4 concentrations to directly assess the relationships among elevated plasma insulin, reduced P450 2A and P450 3A expression, and circulating P4. Further, in the present study, cows received glucose infusions only once during the experiment and the increase in insulin was acute but temporary (Figure 2 ), whereas in the cited studies insulin infusions were administered continuously during a 4-d period (Butler et al., 2003; Lemley et al., 2008) and daily propylene glycol drenches were administered for 35 d (Butler et al., 2006; Lemley et al., 2008) before collection of liver samples. Therefore, it can be theorized that dairy cows in negative nutritional balance require sustained increases in insulin concentrations to inhibit expression of hepatic P450 2A and P450 3A, and thus increase circulating P4 concentrations.

In conclusion, the effects of i.v. glucose infusion on circulating concentrations of insulin and P4 in nonlactating, ovariectomized dairy cows receiving exogenous P4 were dependent on cow nutritional balance. Cows assigned to adequate nutrient intake for $28 \mathrm{~d}$ before infusion and administered $0.5 \mathrm{~g} / \mathrm{kg}$ of BW of glucose had a biphasic increase in serum insulin concentrations and increased serum P4 concentrations compared with cohorts infused with saline. On the other hand, cows 


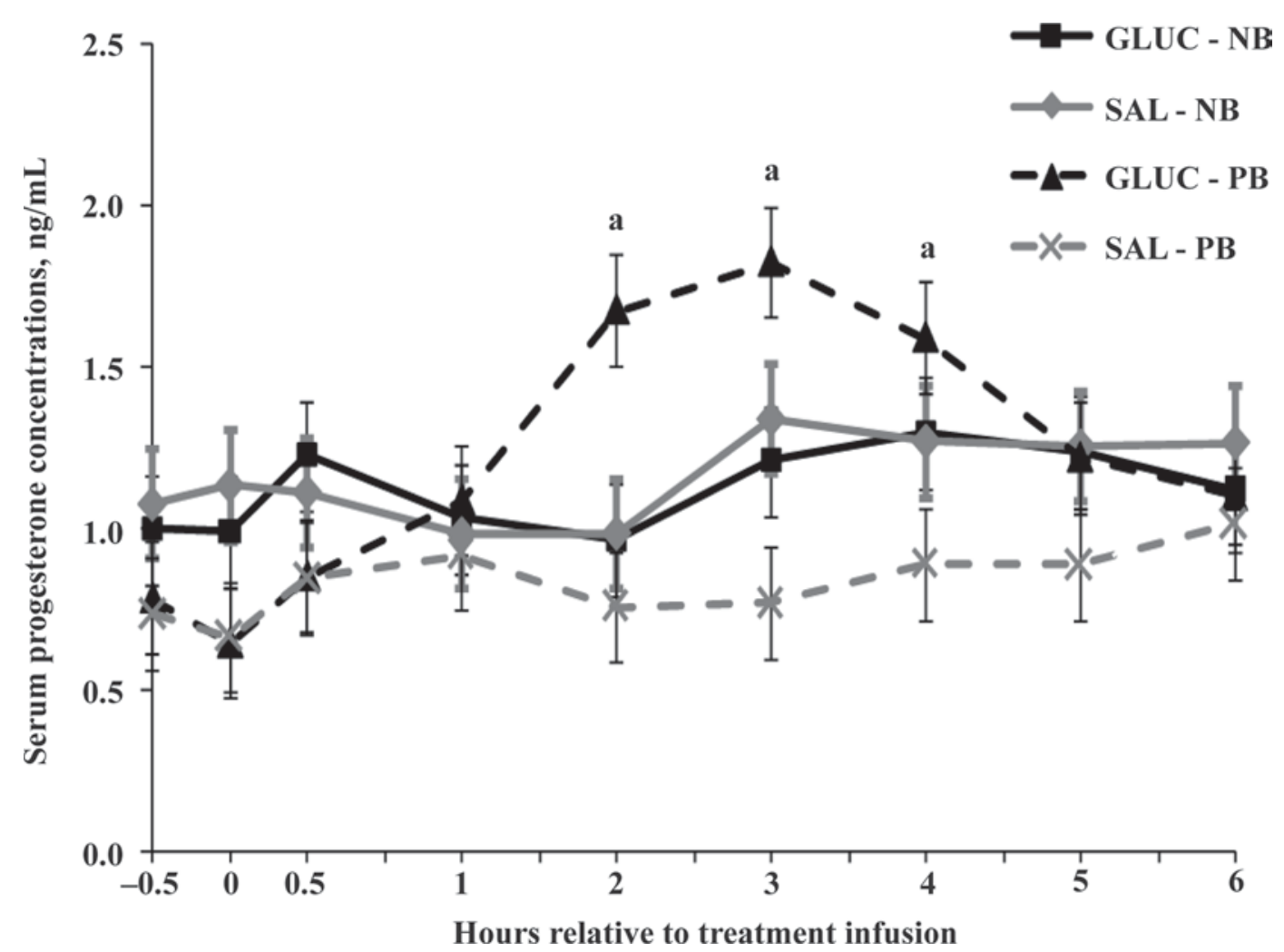

Figure 3. Serum concentrations of progesterone $(\mathrm{ng} / \mathrm{mL})$ in nonlactating cows in negative (NB) or positive (PB) nutrient balance, and infused intravenously with a $5 \%$ glucose solution (GLUC; $0.5 \mathrm{~g}$ of glucose $/ \mathrm{kg}$ of BW, infused on average at $32 \mathrm{~mL} / \mathrm{min}$ over a 3 -h period) or physiological saline (SAL; $0.9 \%$ solution infused on average at $32 \mathrm{~mL} / \mathrm{min}$ over a 3 -h period). Treatments were infused immediately following blood sampling at $0 \mathrm{~h}$. A nutritional treatment $\times$ infusion treatment $\times$ time interaction was detected $(P<0.01)$ mainly because an infusion effect $\times$ time interaction was detected for PB cows $(P<0.01)$ but not for NB cows $(P=0.54)$. Hours with letter designation indicates the following treatment differences $(P<0.01)$ : a $=$ GLUC-PB vs. SAL-PB.

assigned to inadequate nutrient intake for $28 \mathrm{~d}$ before infusion and administered the same dose of glucose had a single-phase increase in serum insulin concentrations, but serum P4 concentrations were similar compared with cohorts infused with saline. Therefore, acute but temporary increases in circulating insulin only modulated $\mathrm{P} 4$ concentrations in cows with adequate nutritional status, whereas cows in negative nutritional balance, such as periparturient dairy cows, may require sustained increases in insulin concentrations to experience similar effects. These physiological mechanisms are important and require further investigation because circulating insulin and P4 are highly associated with reproductive function and success in dairy cattle. An example would be infusing PB and NB cows with exogenous glucose, with or without the addition of exogenous insulin, for longer periods of time. However, caution must be applied when extrapolating the results reported herein to lactating dairy cows. The physiological and metabolic aspects associated with parturition, resumption of reproductive function, and milk synthesis were not accounted for in the present experimental model given that nonlactating ovariectomized cows were used. Also, Gir $\times$ Holstein cows might not fully represent the physiological aspects of a high-producing dairy cow, given that milk yield capacity is considered moderate to low in Gir $\times$ Holstein cows (Madalena et al., 1979).

\section{ACKNOWLEDGMENTS}

We acknowledge Fundação de Amparo à Pesquisa do Estado de São Paulo (FAPESP; grant number 09/506788) for supporting F. V. R. Vieira, an undergraduate student at the Animal Sciences and Veterinary school, São Paulo State University (Universidade Estadual Paulista Júlio de Mesquita Filho), campus Botucatu, São Paulo, Brazil.

\section{REFERENCES}

Bossis, I., R. P. Wettemann, S. D. Welty, J. Vizcarra, and L. J. Spicer. 2000. Nutritionally induced anovulation in beef heifers: Ovarian and endocrine function during realimentation and resumption of ovulation. Biol. Reprod. 62:1436-1444. 
Butler, S. T., A. L. Marr, S. H. Pelton, R. P. Radcliff, M. C. Lucy, and W. R. Butler. 2003. Insulin restores GH responsiveness during lactation-induced negative energy balance in dairy cattle: Effects on expression of IGF-I and GH receptor 1A. J. Endocrinol. 176:205-217.

Butler, S. T., S. H. Pelton, and W. R. Butler. 2006. Energy balance, metabolic status, and the first postpartum ovarian follicle wave in cows administered propylene glycol. J. Dairy Sci. 89:2938-2951.

Butler, W. R. 2005. Inhibition of ovulation in the postpartum cow and the lactating sow. Livest. Prod. Sci. 98:5-12.

Christensen, J. O., R. R. Grummer, F. E. Rasmussen, and S. J. Bertics, 1997. Effect of method of delivery of propylene glycol on plasma metabolites of feed-restricted cattle. J. Dairy Sci. 80:563-568.

Cooke, R. F., and J. D. Arthington. 2009. Plasma progesterone concentrations determined by commercial radioimmunoassay kit as puberty criteria for Brahman-crossbred heifers. Livest. Sci. 123:101-105

Curley, K. O. Jr., D. A. Neuendorff, A. W. Lewis, J. J. Cleere, T. H. Welsh Jr., and R. D. Randel. 2008. Functional characteristics of the bovine hypothalamic-pituitary-adrenal axis vary with temperament. Horm. Behav. 53:20-27.

Demetrio, D. G. B., R. M. Santos, C. G. B. Demetrio, and J. L M. Vasconcelos. 2007. Factors affecting conception rates following artificial insemination or embryo transfer in lactating Holstein cows. J. Dairy Sci. 90:5073-5082.

Diskin, M. G., D. R. Mackey, J. F. Roche, and J. M. Sreenan. 2003. Effects of nutrition and metabolic status on circulating hormones and ovarian follicle development in cattle. Anim. Reprod. Sci. 78:345-370.

FASS. 1999. Guide for the Care and Use of Agricultural Animals in Agricultural Research and Teaching. 1st rev. ed. Federation of Animal Science Societies, Savoy, IL.

Folman, Y., M. Kaim, Z. Herz, and M. Rosenberg. 1990. Comparison of methods for the synchronization of estrous cycles in dairy cows: II. Effects of progesterone and parity on conception. J. Dairy Sci. $73: 2817-2825$

Fonseca, F. A., J. H. Britt, B. T. Daniel, J. C. Wilk, and A. H. Rakes. 1983. Reproductive traits of Holsteins and Jerseys. Effects of age, milk yield, and clinical abnormalities on involution of cervix and uterus, ovulation, estrous cycles, detection of estrus, conception rate, and days open. J. Dairy Sci. 66:1128-1147.

Fox, D. G., L. O. Tedeschi, T. P. Tylutki, J. B. Russell, M. E. Van Amburgh, L. E. Chase, A. N. Pell, and T. R. Overton. 2004. The Cornell Net Carbohydrate and Protein System model for evaluating herd nutrition and nutrient excretion. Anim. Feed Sci. Technol. 112:29-78.

Gong, J. G., W. J. Lee, P. C. Garnsworthy, and R. Webb. 2002. Effect of dietary-induced increases in circulating insulin concentrations during the early postpartum period on reproductive function in dairy cows. Reproduction 123:419-427.

Gonzalez-Padilla, E., J. N. Wiltbank, and G. D. Niswender. 1975. Puberty in beef heifers. The interrelationship between pituitary, hypothalamic and ovarian hormones. J. Anim. Sci. 40:10911104.

Grummer, R. R. 1995. Impact of changes in organic nutrient metabolism on feeding the transition dairy cow. J. Anim. Sci. 73:2820-2833.

Gutiérrez, C. G., J. Oldham, T. A. Bramley, J. G. Gong, B. K. Campbell, and R. Webb. 1997. The recruitment of ovarian follicles is enhanced by increased dietary intake in heifers. J. Anim. Sci. $75: 1876-1884$.

Hamudikuwanda, H., G. Gallo, E. Block, and B. R. Downey. 1996. Adipose tissue progesterone concentrations in dairy cows during late pregnancy and early lactation. Anim. Reprod. Sci. 43:1523.

Henricks, D. M., T. C. Jenkins, J. R. Ward, C. S. Krishnan, and L. Grimes. 1994. Endocrine responses and body composition changes during feed restriction and realimentation in young bulls. J. Anim. Sci. 72:2289-2297.
Hove, K. 1978. Insulin secretion in lactating cows: Responses to glucose infused intravenously in normal, ketonemic, and starved animals. J. Dairy Sci. 61:1407-1413.

Huntington, G. B. 1997. Starch utilization by ruminants: From basics to the bunk. J. Anim. Sci. 75:852-867.

Lapierre, H., J. F. Bernier, P. Dubreuil, C. K. Reynolds, C. Farmer, D. R. Ouellet, and G. E. Lobley. 2000. The effect of feed intake level on splanchnic metabolism in growing beef steers. J. Anim. Sci. 78:1084-1099.

Lemley, C. O., S. T. Butler, W. R. Butler, and M. E. Wilson. 2008. Short communication: Insulin alters hepatic progesterone catabolic enzymes cytochrome P450 2C and 3A in dairy cows. J. Dairy Sci. 91:641-645.

Littell, R. C., P. R. Henry, and C. B. Ammerman. 1998. Statistical analysis of repeated measures data using SAS procedures. J. Anim. Sci. 76:1216-1231.

Looper, M. L., C. A. Lents, and R. P. Wettemann. 2003. Body condition at parturition and postpartum weight changes do not influence the incidence of short-lived corpora lutea in postpartum beef cows. J. Anim. Sci. 81:2390-2394.

Lopes, C. N., A. B. Scarpa, B. I. Cappellozza, R. F. Cooke, and J. L. M. Vasconcelos. 2009. Effects of rumen-protected polyunsaturated fatty acid supplementation on reproductive performance of Bos indicus beef cows. J. Anim. Sci. 87:3935-3943.

Lucy, M. C. 2001. Reproductive loss in high-producing dairy cattle: Where will end? J. Dairy Sci. 84:1277-1293.

Madalena, F. E., M. L. Martinez, and A. F. Freitas. 1979. Lactation curves of Holstein-Friesian and Holstein-Friesian $\times$ Gir cows. Anim. Prod. 29:101-107.

Monget, P., and G. B. Martin. 1997. Involvement of insulin-like growth factors in the interactions between nutrition and reproduction in female mammals. Hum. Reprod. 12:33-52.

Moriel, P., T. S. Scatena, O. G. Sa Filho, R. F. Cooke, and J. L. M. Vasconcelos. 2008. Concentrations of progesterone and insulin in serum of nonlactating dairy cows in response to carbohydrate source and processing. J. Dairy Sci. 91:4616-4621.

Murayama, S., K. Moriya, and Y. Saaki. 1986. Changing pattern of plasma cortisol level associated with feeding in sheep. Jpn. J. Zootech. Sci. 57:317-323.

Murray, M. 1991. Microsomal cytochrome P450-dependent steroid metabolism in male sheep liver. Quantitative importance of $6 \beta$-hydroxylation and evidence for the involvement of a P450 from the IIIA subfamily in the pathway. J. Steroid Biochem. Mol. Biol. 38:611-619.

Nelson, D. L., and M. M. Cox. 2005. Lehninger's Principles of Biochemistry. 4th ed. W. H. Freeman and Company, New York, NY.

Nussey, S. S., and S. A. Whitehead. 2001. Endocrinology: An Integrated Approach. Bios Scientific, Oxford, UK.

O'Connor, T. M., D. J. O'Halloran, and F. Shanahan. 2000. The stress response and the hypothalamic-pituitary-adrenal axis: From molecule to melancholia. Q. J. Med. 93:323-333.

Opsomer, G., Y. T. Grohn, J. Hertl, M. Coryn, H. Deluyker, and A. de Kruif. 2000. Risk factors for post partum ovarian dysfunction in high producing dairy cows in Belgium: A field study. Theriogenology $53: 841-857$.

Reynolds, C. K. 2005. Glucose balance in cattle. Florida Ruminant Nutrition Symposium. http://dairy.ifas.ufl.edu/rns/2005/ Reynolds.pdf Accessed Nov. 14, 2005.

Reynolds, C. K., D. L. Harmon, and M. J. Cecava. 1994. Absorption and delivery of nutrients for milk protein synthesis by portaldrained viscera. J. Dairy Sci. 77:2787-2808.

Sangsritavong, S., D. K. Combs, R. Sartori, and M. C. Wiltbank. 2002. High feed intake increases blood flow and metabolism of progesterone and estradiol- $17 \beta$ in dairy cattle. J. Dairy Sci. $85: 2831-2842$

Spencer, T. E., and F. W. Bazer. 2002. Biology of progesterone action during pregnancy recognition and maintenance of pregnancy. Front. Biosci. 7:1879-1898. 
Spicer, L. J., and S. E. Echternkamp. 1995. The ovarian insulin and insulin-like growth factor system with an emphasis on domestic animals. Domest. Anim. Endocrinol. 12:223-245.

Vasconcelos, J. L. M., S. Sangsritavong, S. J. Tsai, and M. C. Wiltbank. 2003. Acute reduction in serum progesterone concentrations after feed intake in dairy cows. Theriogenology 60:795-807.

Veerkamp, R. F., B. Beerda, and T. van der Lende. 2003. Effects of genetic selection for milk yield on energy balance, levels of hormones, and metabolites in lactating cattle, and possible links to reduced fertility. Livest. Prod. Sci. 83:257-275.

Velez, J. C., and S. S. Donkin. 2005. Feed restriction induces pyruvate carboxylase but not phosphoenolpyruvate carboxykinase in dairy cows. J. Dairy Sci. 88:2938-2948.

Vendramini, J. M. B., L. E. Sollenberger, J. C. B. Dubeux Jr., S. M. Interrante, R. L. Stewart Jr., and J. D. Arthington. 2008. Sward management effects on forage component responses in a production system for early weaned calves. Agron. J. 100:1781-1786.

Vizcarra, J. A., R. P. Wettemann, J. C. Spitzer, and D. G. Morrison. 1998. Body condition at parturition and postpartum weight gain influence luteal activity and concentrations of glucose, insulin, and nonesterified fatty acids in plasma of primiparous beef cows. J. Anim. Sci. 76:927-936.

Ward, J. R., D. M. Henricks, T. C. Jenkins, and W. C. Bridges. 1992. Serum hormone and metabolite concentrations in fasted young bulls and steers. Domest. Anim. Endocrinol. 9:97-103.

Webb, R., P. C. Garnsworthy, J. G. Gong, and D. G. Armstrong. 2004 Control of follicular growth: Local interactions and nutritional influences. J. Anim. Sci. 82(E. Suppl.):E63-E74.

Wettemann, R. P., and I. Bossis. 2000. Nutritional regulation of ovarian function in beef cattle. http://www.asas.org/jas/symposia/ proceedings/0934.pdf Accessed Dec., 2009.

Wildman, E. E., G. M. Jones, P. E. Wagner, R. L. Boman, H. F. Troutt, and T. N. Lesch. 1982. A dairy cow body condition scoring system and its relationship to selected production characteristics. J. Dairy Sci. 65:495-501.

Young, J. W. 1977. Gluconeogenesis in cattle: Significance and methodology. J. Dairy Sci. 60:1-15. 